\title{
Cytotoxicity and Genotoxicity in Allium cepa L. Root Meristem Cells Exposed to the Herbicide Penoxsulam
}

\author{
Seçil Özkan, Recep Liman* \\ Uşak University, Faculty of Arts and Sciences, Molecular Biology and Genetics Department, 64300-Uşak, Turkey \\ *recep.liman@usak.edu.tr \\ Received: 28 February 2019 \\ Accepted: 08 May 2019 \\ DOI: $10.18466 /$ cbayarfbe. 533466
}

\begin{abstract}
Penoxsulam is a new sulfonamide herbicide used on rice crops for annual grasses, broadleaf weeds, and sedges control, either grown through transplanting or direct dry or direct seeding methods of planting. In this study, Allium cepa ana-telophase and comet assay were used to examine the cyto-genotoxic effects of herbicide penoxsulam on A. cepa roots. A. cepa bulbs were exposed to $1 / 2 \mathrm{xEC} 50(12.5 \mu \mathrm{g} / \mathrm{L})$, EC50 (25 $\mu \mathrm{g} / \mathrm{L})$ and $2 \operatorname{xEC} 50(50 \mu \mathrm{g} / \mathrm{L})$ concentrations of penoxsulam for 24, 48, 72 and $96 \mathrm{~h}$. Distilled water and 10 ppm of methyl methanesulfonate (MMS) were used as negative and positive control groups, respectively. Penoxsulam showed a cytotoxic effect by reducing root growth and mitotic index (MI), a genotoxic effect because it statistically increased chromosome aberrations (CAs, anaphase bridge, chromosomal laggards, polyploidy, disturbed ana-telophase and stickiness) and DNA damage as compared to control. Liquid chromatography-tandem mass spectrometry (LC-MS/MS) was also used for quantitative analysis of penoxsulam in A. cepa root meristem cells. Further molecular toxicological evaluations associated in the cyto-genotoxicity of penoxsulam on plants are needed to confirm these results.
\end{abstract}

Keywords: Allium cepa Ana-Telophase Test, Chromosome Aberrations, Comet Assay, Mass Spectrometry, Penoxsulam, Herbicide.

\section{Introduction}

Fluorinated class of triazolopyrimidine sulfonamide herbicides (flumetsulam, florasulam, penoxsulam and pyroxsulam) are one of the Acetolactate Synthase (ALS) inhibitors [1]. ALS enzyme is necessary for the biosynthesis of branched chain amino acids isoleucine, leucine and valine, which is only found in bacteria, plant and fungi but not in mammals. Therefore, they prevent plant growth by preventing cell division. Penoxsulam, registered in 2005, is a new sulfonamide herbicide broadly used on rice crops for annual grasses, broadleaf weeds, and sedges control, either grown through transplanting or direct dry or direct seeding methods of planting [2-4]. So, it's cytotoxic and genotoxic effects on plants should be explored. Some properties about penoxsulam are given Table 1 .

Table 1. Some features of penoxsulam.

\begin{tabular}{|c|c|c|c|c|}
\hline $\begin{array}{l}\text { Chemical } \\
\text { name }\end{array}$ & IUPAC Name & Chemical structure & $\begin{array}{l}\text { Molecular } \\
\text { Weight }\end{array}$ & $\begin{array}{l}\text { Water solubility } \\
\left(\mathrm{mg} / \mathrm{L} \text { at } 20^{\circ} \mathrm{C}\right)\end{array}$ \\
\hline Penoxsulam & $\begin{array}{l}\text { 2-(2,2-difluoroethoxy)-N- } \\
(5,8 \text {-dimethoxy- } \\
{[1,2,4] \text { triazolo[1,5- }} \\
\text { c]pyrimidin-2-yl)-6- } \\
\text { (trifluoromethyl)benzenesul } \\
\text { fonamide }\end{array}$ & $\mathrm{OCH}_{3}$ & $\begin{array}{c}483.37 \\
\mathrm{~g} / \mathrm{mol}\end{array}$ & $\begin{array}{c}5.7 \mathrm{mg} / \mathrm{L} \text { at } \mathrm{pH} 5 \\
408 \mathrm{mg} / \mathrm{L} \text { at } \mathrm{pH} 7 \\
1460 \mathrm{mg} / \mathrm{L} \text { at } \mathrm{pH} 9\end{array}$ \\
\hline
\end{tabular}

Allium test has been frequently used for assessing the toxic effects of pesticides due to its high sensitivity, low cost, availability throughout the year, easy and rapid performance along with small number and large chromosomes. Different parameters (root growth, MI, CAs like c-mitosis, stickiness, bridges, micronucleus etc.) can be assessed easily. It is also validated by International institutions such as UN Environmental
Program, US EPA, WHO and International Program on Plant Bioassay as test organism [5]. DNA damage can be also studied in A. cepa root meristematic cells independent than mitosis through the comet assay which is reproducible, sensitive, inexpensive and wellestablished test for the evaluation of genotoxic effects of pesticides [6]. 
The aim of the study was to investigate the potential cytogenotoxic effects of penoxsulam on onion roots by $A$. cepa ana-telophase and comet tests. LC-MS/MS analysis was also performed to determine the amount of penoxsulam in onion root tips.

\section{Materials and Methods}

\subsection{Materials}

Equal-sized A. cepa L. bulbs (25-30 $\mathrm{mm}$ in diameter) were bought from market without any treatment (Uşak, Turkey). Penoxsulam (CAS Number 219714-96-2) and other chemicals were bought from Sigma Aldrich (Munich, Germany).

\subsubsection{Growth inhibition test}

The growth inhibition test was performed with some modifications as described previously [6] to determine the doses to be utilize for the study of cyto-genotoxic effects of penoxsulam on A. сера root meristem cells. The onions were removed from some brownish bottom plates and yellow-brownish outer surface scales without destroying the root primordia. Concentrations of penoxsulam at $6.25,12.5,25,50,100,250,500$ and 1000 $\mu \mathrm{g} / \mathrm{L}$ and distilled water (control group) were continuously employed the onions at room temperature $\left(21 \pm 4{ }^{\circ} \mathrm{C}\right)$ for $96 \mathrm{~h}$ (Fig. 1.) In the end, whole 50 root bundle from each bulb ( $\mathrm{n}=5$ onion bulbs per exposure) were measured for single control groups and concentration as described by Fiskesjö [7]. The amount of concentration that reduces the root tips growth by $50 \%$ by correlating with negative control group gives $\mathrm{EC}_{50}$ value.

\subsubsection{A. cepa ana-telophase test}

A. cepa ana-telophase test was performed as described by Rank and Nielsen [8] with some modifications. $1 / 2 \times E C 50$ $(12.5 \mu \mathrm{g} / \mathrm{L}), \operatorname{EC} 50(25 \mu \mathrm{g} / \mathrm{L})$ and $2 x E C 50(50 \mu \mathrm{g} / \mathrm{L})$ concentrations of penoxsulam, $10 \mathrm{ppm}$ of MMS (positive control) and distilled water (negative control) were treated with bulbs $(2-3 \mathrm{~cm}$ long roots after 2 days) at room temperature $\left(21 \pm 4{ }^{\circ} \mathrm{C}\right)$ for $24,48,72$ and $96 \mathrm{~h}$. Total number of three onions were utilized to carry out each application. 15-20 root tips $(\sim 1 \mathrm{~cm})$ from each bulb were settled in Carnoy's fixative (glacial acetic acid/absolute ethanol, 1:3) and stocked at $4{ }^{\circ} \mathrm{C}$ for $24 \mathrm{~h}$. After this, the onions were washed and cleaned by pure water and then reserved in $70 \%$ alcohol at the refrigerator until analyses. The roots were incubated in $1 \mathrm{~N} \mathrm{HCl}$ at 60 ${ }^{\circ} \mathrm{C}$ for 8-10 min for hydrolysis. The root tips were cleaned with distilled water thrice and then they were stained with Feulgen method at the room temperature for 25-30 minutes. At the end of the period, 1-2 mm long dark-stained root tips were cut with razor blade and lysed with a drop of $45 \%$ acetic acid. Semi-permanent preparations were prepared by covering finger nail polish. For each application, 1000-1200 cells were counted in five different roots. MI values (expressed as a percentage) were determined by dividing the cells that had undergone mitosis by dividing into the total cells. In order to detect the CAs (Anaphase bridge, chromosome laggards, polyploidy, stickiness and disturbed anaphasetelophase), 500 anaphase-telophase cells (100 cells per slide) were counted in each application group with concentration and shown in the form of percentage [9].

\subsubsection{Comet assay}

This assay was performed according to Tice et al. [10] with some alterations. Seven root tips were cut about 1 $\mathrm{cm}$ long for each experiment and chopped immediately with $600 \mu \mathrm{L}$ precooled Tris- $\mathrm{MgCl}_{2}$ buffer $(0.2 \mathrm{M}$ Tris, 4 $\mathrm{mM} \mathrm{MgCl} 2.6 \mathrm{H}_{2} \mathrm{O}, 0.5 \% \mathrm{w} / \mathrm{v}$ Triton $\left.\mathrm{X}-100, \mathrm{pH} 7.5\right)$ to separate root nuclei in buffer. The sampled obtained were then centrifuged at $1200 \mathrm{rpm}$ at $4{ }^{\circ} \mathrm{C}$ for $7 \mathrm{~min}$. The supernatant was wielded for quantitative analyses, while the pellet was utilized in the comet assay. $50 \mu \mathrm{L}$ of $1.5 \%$ low melting point agarose at $37^{\circ} \mathrm{C}$ was blended with 50 $\mu \mathrm{L}$ of the nuclear suspension. The mixture put on the slide with coated $1 \%$ normal melting point agarose and covered with cover slip. Slides were kept on an icecooled tray for $5 \mathrm{~min}$ to solidify and then gently cover slip was removed. The samples were moved to electrophoresis tank and dipped in the electrophoresis buffer solution ( $1 \mathrm{mM}$ EDTA and $300 \mathrm{mM} \mathrm{NaOH}, \mathrm{pH}>$ 13) for 20 minutes at $4{ }^{\circ} \mathrm{C}$ before the electrophoresis. The electrophoresis was operated at $300 \mathrm{~mA}$ at $25 \mathrm{~V}$ for 20 min. After performing the electrophoresis, the slides were cleaned with distilled water and with neutralization buffer (0.4 M Tris pH 7.5) washed thrice for just 5 min. The staining was done with $70 \mu \mathrm{L} \mathrm{EtBr}$ solution (20 $\mu \mathrm{g} / \mathrm{mL}$ ) for about $5 \mathrm{~min}$. Randomly selected 50 comets per slide (three slides per treatment) to determine the degree of DNA damage between class 0 to 4 (0-no visible damage, 1-low level damage, 2-moderate damage, 3-high level damage and 4-maximal damage) were counted using fluorescence microscope. The arbitrary unit (AU) for DNA damage was evaluated by performing calculation [11].

\subsubsection{Quantitative analysis of penoxsulam in A. cepa root meristem cells by LC-MS/MS}

The quantitative analysis of penoxsulam was performed with LC-MS/MS by using supernatants (described above). An UPLC (Agilent 1200 series) is equipped with cooling system, binary pump, auto-sampler and column oven was used. The 6460 Triple Quadrupole LC-MS/MS system was used for detection of the Mass spectrometry. The mass spectrometer has triple quadrupole was furnished with system of electrospray jet steam ionizer. The ion source is ionization mode in positive electrospray. The MS/MS system was conducted in the multiple reaction monitoring mode. Zorbax Eclipse plus C18 $(2.1 \times 50 \mathrm{~mm}, 2.7 \mu)$ column was applied for chromatographic separation. The mobile phase constitutes of acetonitrile $50 \%$ (mobile phase B) and $0.1 \%$ formic acid in water $50 \%$ (mobile phase A), having column temperature of $40^{\circ} \mathrm{C}$ and $1.2 \mathrm{~mL} / \mathrm{min}$ flow rate. The 2.966-min isocratic elution was achieved using chromatographic separation. The MRM transition was 
detected: $\mathrm{m} / \mathrm{z} 484.1 \rightarrow 194,484.1 \rightarrow 164$ and $484.1 \rightarrow 124$

\subsubsection{Statistical analysis}

One-Way Analysis of Variance (ANOVA) with Duncan multiple range tests $(\mathrm{P}<0.05)$ were used to for the comparison of the results (mean \pm standard deviation) using the IBM SPSS version 23. The dose-response and time-response relationship were determined by Pearson correlation test.

\section{Results and Discussion}

The cytotoxic and genotoxic of penoxsulam detection was carried by Allium Test. As a result of growth inhibition test, the $\mathrm{EC}_{50}$ of penoxsulam was found as approximately $25 \mu \mathrm{g} / \mathrm{L}(49.25 \%)$ as shown in Table 2 and Figure 1. Penoxsulam exposure statistically decreased average root length and dose dependently $(r=-0.982$ $\mathrm{p}=0.01$ ). The average length of Allium root control was $4.67 \pm 0.08 \mathrm{~cm}$, while the root length decreased up to $0.58 \pm 0.07 \mathrm{~cm}$ at $1000 \mu \mathrm{g} / \mathrm{L}$ of penoxsulam. The root length on Oryza sativa was decreased with increasing rates of penoxsulam [12]. Penoxsulam+cyhalofop butyl showed inhibitor effect on the radial mycelial growth of Rhizoctonia solani [13]. $\mathrm{EC}_{50}$ for penoxsulam after 30 days exposure was found $0.72 \mu \mathrm{g} / \mathrm{L}$ for Mytilus galloprovincialis [4]. $\mathrm{EC}_{50}$ for penoxsulam after 66 days was found 12, 64, 630, 51 and $23 \mu \mathrm{g} / \mathrm{L}$ for Scirpus validus
Vahl., Paspalidium geminatum, Panicum hemitomon, Pontederia cordata L. and Sagittaria lancifolia L., respectively [2].

Table 3 illustrates the effect of penoxsulam on MI and mitotic phases in the A. cepa root tips. The value of MI was changed between $61.58 \pm 0.75$ and $48.62 \pm 0.95$ by penoxsulam applications, and statistically these decreasing values were compared with control group. The decreased MI for penoxsulam was found statistically significant not only dose dependently for $24 \mathrm{~h}(\mathrm{r}=-0.943$ $\mathrm{p}=0.01)$, for $48 \mathrm{~h}(\mathrm{r}=-0.97 \mathrm{p}=0.01)$, for $72 \mathrm{~h}(\mathrm{r}=-0.913$ $\mathrm{p}=0.01)$ and for $96 \mathrm{~h}(\mathrm{r}=-0.914 \mathrm{p}=0.01)$ but also time dependently for $12.5 \mu \mathrm{g} / \mathrm{L}(\mathrm{r}=-0.957 \mathrm{p}=0.01)$, for 25 $\mu \mathrm{g} / \mathrm{L}(\mathrm{r}=-0.961 \mathrm{p}=0.01)$ and for $50 \mu \mathrm{g} / \mathrm{L}(\mathrm{r}=-0.94 \mathrm{p}=$ 0.01 ). The $\mathrm{MI}$ in 25 and $50 \mu \mathrm{g} / \mathrm{L}$ at $48,72 \mathrm{~h}$, and $96 \mathrm{~h}$ was lower than MMS. Unlike other result, Scorpion ${ }^{\circledR}$ (flumetsulam as active ingredient, one of the triazolopyrimidine sulfonamide herbicides) induced MI in A. cepa [14].

Penoxsulam treatment statistically decreased prophase index (except at $50 \mu \mathrm{g} / \mathrm{L}$ in $48 \mathrm{~h}$ ) and simultaneous statistically increased telophase index compared to control group. The prophase index reduction (except at $50 \mu \mathrm{g} / \mathrm{L}$ in $48 \mathrm{~h}$ ) may initiate mitosis by halting of interphase as a result of penoxsulam [15] while delay in mitotic cycle accomplishment is due to telophase index increase [16].

Table 2. Allium root growth inhibition test results of penoxsulam.

\begin{tabular}{cccc}
\hline Doses $(\boldsymbol{\mu g} / \mathbf{L})$ & $\begin{array}{c}\text { Average } \\
\text { length } \\
(\mathbf{c m}) \pm \mathbf{S D} *\end{array}$ & $\begin{array}{c}\text { Growth } \\
(\boldsymbol{\%})\end{array}$ & $\begin{array}{c}\text { Decrease } \\
\text { in growth } \\
(\boldsymbol{\%})\end{array}$ \\
\hline Control & $4.67 \pm 0.08 \mathrm{a}$ & 100.00 & 0 \\
6.25 & $2.83 \pm 0.07 \mathrm{~b}$ & 59.53 & 40.47 \\
12.5 & $2.49 \pm 0.06 \mathrm{c}$ & 52.25 & 47.75 \\
25 & $2.35 \pm 0.07 \mathrm{~d}$ & 49.25 & 50.75 \\
50 & $1.83 \pm 0.1 \mathrm{e}$ & 38.54 & 61.46 \\
100 & $1.2 \pm 0.09 \mathrm{f}$ & 25.27 & 74.73 \\
250 & $1.02 \pm 0.05 \mathrm{~g}$ & 21.41 & 78.59 \\
500 & $0.74 \pm 0.06 \mathrm{~h}$ & 15.85 & 84.15 \\
1000 & $0.58 \pm 0.07 \mathrm{i}$ & 12.63 & 87.37 \\
\hline
\end{tabular}

* Means with the same letter do not differ statistically at the level of 0.05.SD: Standard deviation

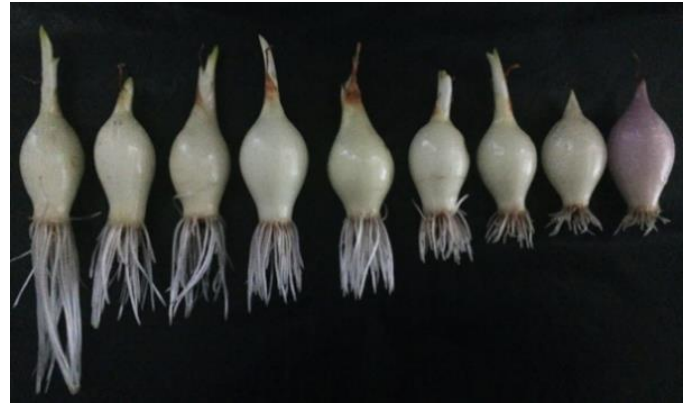

Figure 1. A. cepa roots exposed to penoxsulam after $96 \mathrm{~h}$. Doses from left to right $0,6.25$, $12.5,25,50,100,250,500$ and $1000 \mu \mathrm{g} / \mathrm{L}$. 
Table 3. Changes of mitotic and phase index of A. cepa root meristematic cells treated with penoxsulam.

\begin{tabular}{cllllll}
\hline $\begin{array}{c}\text { Concentration } \\
(\boldsymbol{\mu g} / \mathbf{L})\end{array}$ & $\mathbf{C C N}$ & $\mathbf{M I} \pm$ SD* & \multicolumn{4}{c}{ Phase index (\%) \pm SD* } \\
\cline { 4 - 6 } Control-24 h & 5080 & $71.69 \pm 0.61 \mathrm{a}$ & $89.35 \pm 0.79 \mathrm{a}$ & $1.81 \pm 0.19 \mathrm{a}$ & $2.45 \pm 0.28 \mathrm{a}$ & $6.39 \pm 0.6 \mathrm{a}$ \\
MMS-10 ppm & 5134 & $56.51 \pm 0.53 \mathrm{~b}$ & $88.03 \pm 0.9 \mathrm{~b}$ & $2.83 \pm 0.34 \mathrm{~b}$ & $2.52 \pm 0.41 \mathrm{a}$ & $6.62 \pm 0.36 \mathrm{a}$ \\
12.5 & 5113 & $61.58 \pm 0.75 \mathrm{c}$ & $85.68 \pm 0.98 \mathrm{c}$ & $2.51 \pm 0.31 \mathrm{~b}$ & $2.73 \pm 0.6 \mathrm{a}$ & $9.08 \pm 0.52 \mathrm{c}$ \\
25 & 5093 & $58.53 \pm 0.67 \mathrm{~d}$ & $84.61 \pm 0.37 \mathrm{~d}$ & $2.45 \pm 0.28 \mathrm{~b}$ & $2.61 \pm 0.24 \mathrm{a}$ & $10.33 \pm 0.35 \mathrm{~d}$ \\
50 & 5032 & $57.07 \pm 0.25 \mathrm{~b}$ & $87.46 \pm 0.45 \mathrm{~b}$ & $2.51 \pm 0.2 \mathrm{~b}$ & $2.58 \pm 0.45 \mathrm{a}$ & $7.45 \pm 0.38 \mathrm{e}$ \\
Control-48 h & 5080 & $70.29 \pm 0.8 \mathrm{a}$ & $88.88 \pm 0.29 \mathrm{ab}$ & $2.41 \pm 0.2 \mathrm{a}$ & $2.8 \pm 0.22 \mathrm{a}$ & $5.91 \pm 0.33 \mathrm{a}$ \\
MMS-10 ppm & 5072 & $55.45 \pm 0.93 \mathrm{~b}$ & $88.44 \pm 0.62 \mathrm{a}$ & $2.24 \pm 0.14 \mathrm{ab}$ & $2.7 \pm 0.32 \mathrm{a}$ & $6.62 \pm 0.49 \mathrm{~b}$ \\
12.5 & 5040 & $58 \pm 0.76 \mathrm{c}$ & $86.15 \pm 0.88 \mathrm{c}$ & $2.16 \pm 0.3 \mathrm{ab}$ & $2.74 \pm 0.28 \mathrm{a}$ & $8.96 \pm 0.67 \mathrm{c}$ \\
25 & 5090 & $55.19 \pm 0.6 \mathrm{~b}$ & $87.54 \pm 0.41 \mathrm{~d}$ & $1.99 \pm 0.2 \mathrm{~b}$ & $2.49 \pm 0.18 \mathrm{a}$ & $7.98 \pm 0.5 \mathrm{~d}$ \\
50 & 5080 & $51.97 \pm 0.66 \mathrm{~d}$ & $89.71 \pm 0.87 \mathrm{~b}$ & $1.63 \pm 0.19 \mathrm{c}$ & $1.97 \pm 0.2 \mathrm{~b}$ & $6.7 \pm 0.62 \mathrm{~b}$ \\
Control-72 h & 5117 & $70.32 \pm 0.53 \mathrm{a}$ & $89.47 \pm 0.63 \mathrm{a}$ & $2.05 \pm 0.25 \mathrm{a}$ & $2.59 \pm 0.38 \mathrm{a}$ & $5.89 \pm 0.46 \mathrm{a}$ \\
MMS-10 ppm & 5091 & $54.18 \pm 0.84 \mathrm{~b}$ & $88.83 \pm 0.54 \mathrm{ab}$ & $2.1 \pm 0.5 \mathrm{a}$ & $2.65 \pm 0.42 \mathrm{a}$ & $6.42 \pm 0.42 \mathrm{a}$ \\
12.5 & 5153 & $55.05 \pm 0.99 \mathrm{~b}$ & $88.66 \pm 0.21 \mathrm{c}$ & $2.19 \pm 0.29 \mathrm{a}$ & $2.36 \pm 0.28 \mathrm{a}$ & $7.79 \pm 0.36 \mathrm{~b}$ \\
25 & 5122 & $51.62 \pm 0.57 \mathrm{c}$ & $88.13 \pm 0.97 \mathrm{bc}$ & $2.08 \pm 0.3 \mathrm{a}$ & $2.35 \pm 0.42 \mathrm{a}$ & $7.45 \pm 0.54 \mathrm{~b}$ \\
50 & 5117 & $50.48 \pm 0.46 \mathrm{~d}$ & $88.11 \pm 0.78 \mathrm{bc}$ & $2.05 \pm 0.35 \mathrm{a}$ & $2.36 \pm 0.37 \mathrm{a}$ & $7.47 \pm 0.68 \mathrm{~b}$ \\
Control-96 h & 5113 & $69.88 \pm 0.7 \mathrm{a}$ & $89.48 \pm 0.46 \mathrm{a}$ & $2.07 \pm 0.3 \mathrm{a}$ & $2.71 \pm 0.22 \mathrm{ab}$ & $5.74 \pm 0.43 \mathrm{a}$ \\
MMS-10 & 5151 & $53.42 \pm 0.23 \mathrm{~b}$ & $88.38 \pm 0.45 \mathrm{~b}$ & $2.07 \pm 0.37 \mathrm{a}$ & $2.76 \pm 0.24 \mathrm{~b}$ & $6.79 \pm 0.39 \mathrm{~b}$ \\
12.5 & 5128 & $53.53 \pm 0.86 \mathrm{~b}$ & $88.16 \pm 0.84 \mathrm{~b}$ & $2.19 \pm 0.4 \mathrm{a}$ & $2.26 \pm 0.41 \mathrm{a}$ & $7.39 \pm 0.62 \mathrm{~b}$ \\
25 & 5142 & $50.43 \pm 0.98 \mathrm{c}$ & $88.01 \pm 0.74 \mathrm{~b}$ & $2.04 \pm 0.28 \mathrm{a}$ & $2.51 \pm 0.46 \mathrm{ab}$ & $7.44 \pm 0.62 \mathrm{~b}$ \\
50 & 5190 & $48.62 \pm 0.95 \mathrm{~d}$ & $88.19 \pm 0.42 \mathrm{~b}$ & $2.02 \pm 0.2 \mathrm{a}$ & $2.46 \pm 0.29 \mathrm{ab}$ & $7.33 \pm 0.48 \mathrm{~b}$ \\
\hline
\end{tabular}

*Means with the same letter in the same column for each application time do not differ statistically at the level of 0.05 . CCN: Counting Cell Numbers. SD: Standard Deviation.

Different types of CAs were induced by penoxsulam in A. сера root ana-telophase cells are shown in Table 4 and Figure 2. Total CA frequency was increased significantly and dose dependently for $24 \mathrm{~h}(\mathrm{r}=0.686 \mathrm{p}=0.01)$, for 48 $\mathrm{h}(\mathrm{r}=0.641 \mathrm{p}=0.05)$, for $72 \mathrm{~h}(\mathrm{r}=0.796 \mathrm{p}=0.01)$ and for $96 \mathrm{~h}(\mathrm{r}=0.526 \mathrm{p}=0.05)$ and also time dependently for $12.5 \mu \mathrm{g} / \mathrm{L}(\mathrm{r}=0.788 \mathrm{p}=0.01)$, for $25 \mu \mathrm{g} / \mathrm{L}(\mathrm{r}=0.749 \mathrm{p}=$ $0.01)$ and for $50 \mu \mathrm{g} / \mathrm{L}(\mathrm{r}=0.821 \mathrm{p}=0.01)$. But these CAs were lower than MMS. While the most visible CAs of penoxsulam was a stickiness ( $4 \%$ at $12.5 \mu \mathrm{g} / \mathrm{L}$ for $96 \mathrm{~h}$ ), the least visible CAs of penoxsulam was an anaphase bridge $(0.4 \%$ at $50 \mu \mathrm{g} / \mathrm{L}$ for $24 \mathrm{~h})$. Unlike other result, penoxsulam did not show any genotoxic potential in Chinese hamster ovary cells, Escherichia coli, Salmonella typhimurium, rat lymphocytes and mouse bone marrow cells [17].

Table 5 presents the results of the comet assay obtained in A. сера root meristamic cells after exposure penoxsulam. Penoxsulam induced DNA damage dose dependently for $24 \mathrm{~h}(\mathrm{r}=0.933 \mathrm{p}=0.01)$, for $48 \mathrm{~h}(\mathrm{r}=$ $0.959 \mathrm{p}=0.01)$, for $72 \mathrm{~h}(\mathrm{r}=0.968 \mathrm{p}=0.01)$ and for $96 \mathrm{~h}$ $(\mathrm{r}=0.927 \mathrm{p}=0.01)$ and also time dependently for 12.5 $\mu \mathrm{g} / \mathrm{L}(\mathrm{r}=0.919 \mathrm{p}=0.01)$, for $25 \mu \mathrm{g} / \mathrm{L}(\mathrm{r}=0.908 \mathrm{p}=0.01)$ and for $50 \mu \mathrm{g} / \mathrm{L}(\mathrm{r}=0.842 \mathrm{p}=0.01)$. The highest DNA damage $(141 \pm 2.65)$ was obtained from $50 \mu \mathrm{g} / \mathrm{L}$ of penoxsulam for $96 \mathrm{~h}$ and the lowest one $(63 \pm 2.65)$ at 12.5 $\mu \mathrm{g} / \mathrm{L}$ of penoxsulam for $24 \mathrm{~h}$. DNA damage treated with $50 \mu \mathrm{g} / \mathrm{L}$ of penoxsulam (except $24 \mathrm{~h}$ ) was higher than MMS. Penoxsulam caused induction of ROS production and DNA damage by comet assay in hemocytes of Mytilus galloprovincialis after 15 and 30 days [4]. Costa et al. [18] showed that penoxsulam induced DNA damage to the Procambarus clarkii. Penoxsulam also induced oxidative stress in Oryza sativa [19] and Oreochromis niloticus [20]. Penoxsulam exposure in the A. cepa might result in generation of ROS which could decrease root growth and MI and also increase CAs and DNA damage. 
Table 4. Genotoxic effects of penoxsulam on A. cepa root cells.

\begin{tabular}{cccccccc}
\hline \multirow{2}{*}{$\begin{array}{c}\text { Concentration } \\
(\boldsymbol{\mu g} / \mathbf{L})\end{array}$} & \multirow{2}{*}{$\mathbf{C C N}$} & $\mathrm{DAT}$ & $\mathrm{CL}$ & $\mathrm{S}$ & $\mathrm{P}$ & $\mathrm{AB}$ & TA \pm SD* \\
\cline { 2 - 7 } Control-24 h & 500 & 1.2 & 0.8 & 0.4 & 0.8 & 0.2 & $\mathbf{3 . 4} \pm \mathbf{0 . 5 5 a}$ \\
MMS-10 ppm & 500 & 2.2 & 3.2 & 3.2 & 3.8 & 1.6 & $\mathbf{1 4} \pm .1 .00 b$ \\
12.5 & 500 & 2.4 & 3.6 & 3.4 & 0.8 & - & $\mathbf{1 0 . 2} \pm \mathbf{0 . 4 5 c}$ \\
25 & 500 & 2.4 & 2.8 & 2.6 & 1.8 & 0.8 & $\mathbf{1 0 . 6} \pm \mathbf{0 . 8 9 c}$ \\
50 & 500 & 1.8 & 3.4 & 3.6 & 2.4 & 0.4 & $\mathbf{1 1 . 6} \pm \mathbf{0 . 5 5 d}$ \\
Control-48 h & 500 & 0.2 & 1 & 0.6 & 0.8 & - & $\mathbf{2 . 6} \pm \mathbf{0 . 5 5 a}$ \\
MMS-10 ppm & 500 & 3 & 3.2 & 3.2 & 3.4 & 2.2 & $\mathbf{1 4 . 8} \pm \mathbf{0 . 4 5 b}$ \\
12.5 & 500 & 2.2 & 2.6 & 3.2 & 1.8 & 0.6 & $\mathbf{1 0 . 4} \pm \mathbf{0 . 8 9 c}$ \\
25 & 500 & 2 & 2.8 & 2.6 & 3. & 1.4 & $\mathbf{1 1 . 8} \pm \mathbf{0 . 8 4 d}$ \\
50 & 500 & 2 & 3 & 2.6 & 3.2 & 1.2 & $\mathbf{1 2} \pm \mathbf{0 . 7 1 d}$ \\
Control-72 h & 500 & 0.8 & 1 & 0.6 & 0.8 & - & $\mathbf{3 . 2} \pm \mathbf{0 . 8 4 a}$ \\
MMS-10 ppm & 500 & 2.6 & 3.4 & 3.4 & 3.2 & 2.4 & $\mathbf{1 5} \pm \mathbf{0 . 7 1 b}$ \\
12.5 & 500 & 2.2 & 3.2 & 3.2 & 2.2 & 0.8 & $\mathbf{1 1 . 8} \pm \mathbf{0 . 4 5 c}$ \\
25 & 500 & 2.6 & 2.8 & 2.8 & 3.2 & 1.2 & $\mathbf{1 2 . 6} \pm \mathbf{0 . 5 5 c d}$ \\
50 & 500 & 2.8 & 3 & 2.8 & 3 & 1.4 & $\mathbf{1 3 . 2} \pm \mathbf{0 . 4 5 d}$ \\
Control-96 h & 500 & 0.6 & 1 & 0.6 & 1.2 & 0.2 & $\mathbf{3 . 6} \pm \mathbf{0 . 8 9 a}$ \\
MMS-10 ppm & 500 & 2.6 & 3.2 & 3.6 & 3.4 & 2.4 & $\mathbf{1 5 . 2} \pm \mathbf{0 . 8 4 b}$ \\
12.5 & 500 & 2 & 3.2 & 4 & 2 & 1.4 & $\mathbf{1 2 . 6} \pm \mathbf{1 . 1 4 c}$ \\
25 & 500 & 2 & 3.2 & 3 & 3.4 & 1.2 & $\mathbf{1 2 . 8} \pm \mathbf{0 . 8 4 c d}$ \\
50 & 500 & 2.8 & 3.6 & 3.4 & 3.2 & 1 & $\mathbf{1 4} \pm \mathbf{1 b d}$ \\
\hline
\end{tabular}

*Means with the same letter in the same column for each application time do not differ statistically at the level of 0.05. SD: Standard Deviation. CCN: Counting Cell Numbers. DAT: Disturbed Anaphase-Telophase. CL: Chromosome Laggards. S: Stickiness. P: Polyploidy. AB: Anaphase Bridge. TA: Total Anomalies

Table 5. DNA damage in A. cepa bulbs treated with penoxsulam.

\begin{tabular}{cccccc}
\hline \multirow{2}{*}{ Compounds } & $\begin{array}{c}\text { Concentration } \\
(\boldsymbol{\mu g} / \mathbf{L})\end{array}$ & \multicolumn{4}{c}{ DNA Damage (Arbitrary Unit \pm SD) } \\
\cline { 3 - 6 } & - & $24 \mathbf{~ h}$ & $\mathbf{4 8 ~ h}$ & $\mathbf{7 2} \mathbf{~ h}$ & $\mathbf{9 6} \mathbf{~ h}$ \\
\hline Negative control & $10 \mathrm{ppm}$ & $108 \pm 4.36 \mathrm{~b}$ & $119.33 \pm 3.21 \mathrm{~b}$ & $124.33 \pm 1.53 \mathrm{~b}$ & $126.33 \pm 1.53 \mathrm{~b}$ \\
MMS & 12.5 & $63 \pm 2.65 \mathrm{c}$ & $77.67 \pm 2.52 \mathrm{c}$ & $88.33 \pm 2.08 \mathrm{c}$ & $90.67 \pm 2.31 \mathrm{c}$ \\
\multirow{3}{*}{ Penoxsulam } & 25 & $70.33 \pm 2.31 \mathrm{~d}$ & $115.67 \pm 2.08 \mathrm{~b}$ & $121.33 \pm 2.52 \mathrm{~b}$ & $133 \pm 2 \mathrm{~d}$ \\
& 50 & $101 \pm 3.61 \mathrm{e}$ & $129.33 \pm 3.79 \mathrm{~d}$ & $135 \pm 2 \mathrm{~d}$ & $141 \pm 2.65 \mathrm{e}$ \\
\hline
\end{tabular}

* Means with the same letter do not differ statistically at the level of 0.05. SD: Standard Deviation

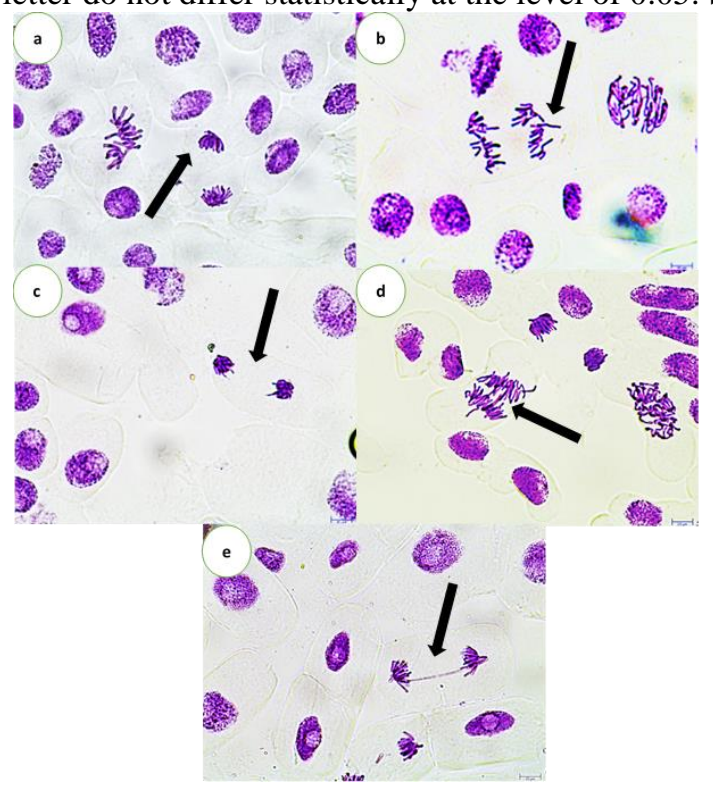

Figure 2. Anaphase-telophase anomalies induced by penoxsulam in A. cepa roots, a: Disturbed ana-telophase, b: Chromosome Laggards, c: Stickiness, d: Poliploidy e: Anaphase Bridge. 
The A. cepa root cell quantitative analysis of penoxsulam by LC-MS/MS is shown Table 6 . The penoxsulam amount observed was increased, both in terms of concentration (for $24 \mathrm{~h} \mathrm{r}=0.714 \mathrm{p}=0.01$, for $48 \mathrm{~h} \mathrm{r}=$ $0.693 \mathrm{p}=0.01$, for $72 \mathrm{~h} \mathrm{r}=0.753 \mathrm{p}=0.01$ and for $96 \mathrm{~h} \mathrm{r}=$ $0.894 \mathrm{p}=0.01$ ) and duration (for $25 \mu \mathrm{g} / \mathrm{L} \mathrm{r}=0.725 \mathrm{p}=$
0.01 and for $50 \mu \mathrm{g} / \mathrm{Lr}=0.792 \mathrm{p}=0.01)$. The highest value $(0.0057 \pm 0.0012 \mathrm{ppb})$ was obtained from $50 \mu \mathrm{g} / \mathrm{L}$ of penoxsulam in $96 \mathrm{~h}$, and the lowest one $(0.0012 \pm 0.0004$ $\mathrm{ppb}$ ) was at $12.5 \mu \mathrm{g} / \mathrm{L}$ of penoxsulam in $24 \mathrm{~h}$.

Table 6. Quantitative analysis of penoxsulam.

\begin{tabular}{|c|c|c|c|c|c|}
\hline \multirow{2}{*}{ Compounds } & \multirow{2}{*}{$\begin{array}{c}\text { Concentration } \\
(\mu \mathrm{g} / \mathrm{L})\end{array}$} & \multicolumn{4}{|c|}{ Amount (ppb \pm SD)* } \\
\hline & & $24 \mathrm{~h}$ & $48 \mathrm{~h}$ & $72 \mathrm{~h}$ & $96 \mathrm{~h}$ \\
\hline \multirow{2}{*}{$\begin{array}{c}\text { Negative control } \\
\text { MMS }\end{array}$} & - & - & - & - & - \\
\hline & $10 \mathrm{ppm}$ & - & - & - & - \\
\hline \multirow{3}{*}{ Penoxsulam } & 12.5 & $0.0012 \pm 0.0004 \mathrm{a}$ & $0.0013 \pm 0.0005 \mathrm{a}$ & $0.0015 \pm 0.00005 \mathrm{a}$ & $0.0017 \pm 0.0005 a$ \\
\hline & 25 & $0.0015 \pm 0.0005 a$ & $0.0017 \pm 0.0005 \mathrm{a}$ & $0.0018 \pm 0.0004 \mathrm{a}$ & $0.0037 \pm 0.0008 b$ \\
\hline & 50 & $0.0023 \pm 0.0005 b$ & $0.0025 \pm 0.0005 b$ & $0.0043 \pm 0.0015 b$ & $0.0057 \pm 0.0012 \mathrm{c}$ \\
\hline
\end{tabular}

* Means with the same letter in columns do not differ statistically at the level of 0.05 . ppb: parts per billion. SD: Standard Deviation.

\section{Conclusion}

Results showed that penoxsulam induces cytotoxicity by reduction in root growth and $\mathrm{MI}$ and genotoxicity by increasing CAs and DNA damage to A. cepa roots. It should be considered when using because it poses a potential hazard to non-target organism. Further molecular toxicological evaluations involved in the cytogenotoxicity of penoxsulam on plants are needed to confirm these results.

\section{Acknowledgement}

The authors acknowledge Uşak University Scientific Analysis Technological Application and Research Center (UBATAM) for LC-MS/MS analysis.

\section{Author's Contributions}

Seçil Özkan: Drafted and wrote the manuscript, performed the experiment and result analysis.

Recep Liman: Assisted in analytical analysis on the structure, supervised the experiment's progress, result interpretation and helped in manuscript preparation.

\section{Ethics}

There are no ethical issues after the publication of this manuscript.

\section{References}

1. Fujiwara, TO, Hagan, D. 2014. Successful fluorine-containing herbicide agrochemicals. Journal of Fluorine Chemistry; 167: 1629.

2. Koschnick, TJ, Netherland, MD, Haller, WT. 2007. Effects of three als-inhibitors on five emergent native plant species in Florida. Journal of Aquatic Plant Management; 45: 47-51.

3. Jabusch, TW, Tjeerdema, RS. 2005. Partitioning of penoxsulam, a new sulfonamide herbicide. Journal of Agrlcultural and Food Chemistry; 53(18): 7179-7183.

4. Patetsini, E, Dimitriadis, VK, Kaloyianni, M. 2013. Biomarkers in marine mussels, Mytilus galloprovincialis, exposed to environmentally relevant levels of the pesticides, chlorpyrifos and penoxsulam. Aquatic Toxicology; 126: 338-345.

5. Leme, DM, Marin-Morales, MA. 2009. Allium cepa test in environmental monitoring: a review on its application. Mutation Research-Reviews in Mutation Research; 682(1): 71-81.
6. Liman, R, Cigerci, IH, Akyil, D, Eren, Y. 2011. Konuk M. Determination of genotoxicity of fenaminosulf by allium and comet tests. Pesticide Biochemistry and Physiology; 99, 61-64.

7. Fiskesjö, G. 1988. The allium test-an alternative in environmental studies: the relative toxicity of metal ions. Mutation Research; 197: 243-260.

8. Rank, J, Nielsen, MH. 1994. Evaluation of the allium anaphasetelophase test in relation to genotoxicity screening of industrial wastewater. Mutation Research-Environmental Mutagenesis and Related Subjects; 312(1): 17-24.

9. Saxena, PN, Chauhan, LKS, Gupta, SK. 2005. Cytogenetic effects of commercial formulation of cypermethrin in root meristem cells of Allium sativum: spectroscopic basis of chromosome damage. Toxicology; 216(2-3): 244-252.

10. Tice, RR, Agurell, E, Anderson, D, Burlinson, B, Hartman, A, Kobayashi, H, Sasaki, YF. 2000. Single cell gel/comet assay: guidelines for in vitro and in vivo genetic toxicology testing. Environmental and Molecular Mutagenesis; 35(3): 206-221.

11. Koçyiğit, A, Keles, H, Selek, S, Guzel, S, Celik, H, Erel, O. 2005. Increased DNA damage and oxidative stress in patients with cutaneous leishmaniasis. Mutation Research; 585: 71-78.

12. Concenço, G, Lopes, NF, Moraes, DM, Andres, A, Melo, PTBS. 2006. Rice seedling and plant development as affected by increasing rates of penoxsulam under controlled environments. Planta Daninha; 24(1): 131-139.

13. Raj, SK, Syriac, EK, Geetha, D. 2018. Non-target effect of herbicide mixtures on the mycelial growth of Rhizoctonia solani kuhn. Japanese Journal of Tropical Agriculture; 55(2): 214-219.

14. Silveira, MAD, Ribeiro DL, De Castro Marcondes, JP, D'arce, LPG. 2016. Sulfentrazone and flumetsulam herbicides caused DNA damage and instability in Allium cepa test. International Journal of Education and Applied Research; 2(8): 1-7.

15. Soliman, MI, Ghoneam, GT. 2004. The mutagenic potentialities of some herbicides using Vicia faba as a biological system. Biotechnology Journal; 3: $140-154$.

16. Rangaswamy, V, Shanthamurthy, KB, Arekal, GD. 1979. Cytological effects of industrial effluent on somatic cells of Allium cepa. Cytologia; 44: 921926

17. Billington, R, Gehen, SC, Hanley, TR. Toxicology of Triazolopyrimidine Herbicides. In: Robert K (ed) Hayes' Handbook of Pesticide Toxicolog, 3rd edn. Academic Press, United States, 2010, pp 1865-1885.

18. Costa, R, Pereira, JL, Santos, MA, Pacheco, M, Guilherme, S. 2018. The role of contamination history and gender on the genotoxic responses of the crayfish Procambarus clarkii to a penoxsulam-based herbicide. Ecotoxicology; 27(7): 908-918.

19. Nohatto, MA, Agostinetto, D, Langaro, AC, Oliveira, CD, Ruchel, Q. 2016. Antioxidant activity of rice plants sprayed with herbicides. Pesquisa Agropecuária Tropical; 46(1): 28-34.

20. Galal, AA, Reda, RM, Mohamed, AAR. 2018. Influences of Chlorella vulgaris dietary supplementation on growth performance, hematology, immune response and disease resistance in Oreochromis niloticus exposed to sub-lethal concentrations of penoxsulam herbicide. Fish and Shellfish Immunology; 77: 445-456. 